\title{
Differential Sensitivity of Growth and Net Photosynthetic Rates in Five Tree Species Seedlings under Simulated Acid Rain Stress
}

\author{
Senmiao Tong, Liqin Zhang* \\ National Engineering Laboratory of Biopesticide Preparation, School of Forestry and Biotechnology, \\ Zhejiang Agriculture and Forestry University, Linan 311300, Zhejiang, People's Republic of China \\ Received: 26 February 2014 \\ Accepted: 9 May 2014
}

\begin{abstract}
This study investigated the effect of simulated acid rain (SAR) (heavy: $\mathrm{pH} 2.5$; moderate: $\mathrm{pH} 4.0$; and control: $\mathrm{pH}$ 5.6) stress on the growth and net photosynthetic rate (Pn) of five tree species, namely Castanopsis sclerophylla, Cinnamomum camphora, Manglietia fordiana, Pinus massoniana, and Elaeocarpus glabripetalus. Results showed variable responses to SAR with different $\mathrm{pH}$ values depending on the type of plants. P. massoniana seedlings exhibited significant growth reduction in response to all of the SAR treatments. The net photosynthetic rate of $P$. massoniana treated by SAR decreased by 20 and $34 \%$ under $\mathrm{pH} 4$ and 2.5 , suggesting that $P$. massoniana was susceptible when exposed to acid rain. These results indicate that $P$. massoniana was the highest sensitivity inhibitory type to SAR and should be protected. However, the growth, chlorophyll content, and Pn of three species (C. sclerophylla, C. camphora, M. fordiana) revealed the following result: moderate acid rain $>$ control $>$ heavy acid rain, suggesting that moderate acid rain promoted photosynthesis and growth to some extent. Among the five species, E. glabripetalus exhibited the highest extent of tolerance to acid rain. The sensitivity of growth and Pn of E. glabripetalus was significantly higher than that of the control, indicating that SAR promoted rather than inhibited its seedling, E. glabripetalus belonging to the promotional type. The stress tolerance of five species of trees to SAR was observed in the following order: E. glabripetalus $>C$. sclerophylla, C. camphora, M. fordiana $>$ P. massoniana. But exposure to SAR at $\mathrm{PH} 2.5$ to 5.6 did not affect the final mortality of five tree species.
\end{abstract}

Keywords: simulated acid rain stress, growth, net photosynthetic rate, species sensitivity, environmental protection

\section{Introduction}

Nowadays, acid rain has been recognized as one of the major environmental issues due to inadvertent human interference such as combustion of fossil fuels and industrial processes $[1,2]$. It has become one of the top 10 global environmental issues, causing slower growth, injury, or other negative impact to forest ecosystems [3]. The effects

*e-mail: zhangliqinlxy@163.com of acid rain on plants can be determined at several levels, particularly from the changes in biochemical and physiological processes through organs and whole plant response, including the visible symptoms of injury and other effects such as reduced photosynthesis, and variations in enzyme activities [4]. Biochemical processes may be significantly detected earlier than the changes in growth and yield because the latter becomes apparent only after plants are exposed to relatively long periods of acid rain [5]. Remarkable effects on forests have been observed in 
south China since the late 1970s and this situation has continuously deteriorated [6]. Large soil areas in southern China have been highly acidified and heavily polluted.

Monitoring data from 1993 to 2004 in southwest China showed that $23.53 \%$ of the monitoring stations recorded rainwater with $\mathrm{pH}<4.0,17.65 \%$ with $\mathrm{pH}<4.5$, and $47.06 \%$ with $\mathrm{pH}<5.6$ [7]. Acid rain is one of the most serious emerging environmental problems because of air pollution [8]. Acid precipitation may result in visible toxicity symptoms in plants, including chlorotic spot and necrotic spot in leaves. Acid rain also elicits other negative effects, such as inhibiting photosynthesis, flushing off nutritive elements, disrupting water balance, and reducing enzyme activities $[9,10]$. Therefore, researchers have suggested that acid rain is a possible contributor to forest decline [11, 12]. However, besides the inhibitory effects, acid rain may have promotional effects on plants [13]. For instance acid rain contains a mixture of a variety of substances including ions such as $\mathrm{H}^{+}, \mathrm{SO}_{4}^{2-}, \mathrm{NO}_{3}^{-}, \mathrm{Cl}^{-}, \mathrm{NH}_{4}^{+}, \mathrm{K}^{+}$, and $\mathrm{Ca}^{2+}$, which are essential mineral elements required by plants [14]. Other plants depend on acid rain to acquire nutrients; hence this system is complex and dynamic.

Acid rain results in soil acidification, which increases the exchange between hydrogen ions and nutrient cations such as potassium $(\mathrm{K})$ and calcium $(\mathrm{Ca})$ in plants. As a result, acid rain elicits a two-sided effect on trees [15]. Thus acid rain-tolerant plants can be used not only to alleviate vegetation degradation but also to increase the biodiversity and productivity of the ecosystem in this acid rain-prone region [16]. The effects of different types of simulated acid rain (SAR) on tree plants have been occasionally studied [17]. Castanopsis sclerophylla, Cinnamomum camphora, Manglietia fordiana, Pinus massoniana, and Elaeocarpus glabripetalus are heliophilous and dominant species in forest ecosystems that are distributed in large areas in southern China [18]. However, limited information is available regarding the responses to SAR and the mechanisms by which acid rain affects these trees [19].

The detrimental effects of acid rain greatly depend on the acidity of the rain. Rain with $\mathrm{pH}<3.0$ can cause significant damage to trees [20]. Therefore, the effects of different $\mathrm{pH}$ levels of SAR on the growth, chlorophyll content, and net photosynthetic rate (Pn) of trees should be further clarified in detail. In China, the rain monitoring data have indicated that rain is acidic in most places, where $\mathrm{pH}$ ranges from 2.3 to 4.4 [21]. The forest and agricultural region of southern China receives acidic precipitation with an annual weighted-mean $\mathrm{pH}$ of 3.6. However, $\mathrm{pH}$ varies with time [22]. This study aimed to investigate the relative sensitivity of five economical important trees species to acidic rain. The response of these five species to SAR exhibited a practical significance in forest protection. This study also aimed to determine the relative susceptibility of five economically tree species to environmental stress and provide the basis of appropriate tree or plant species selection for the ecological restoration of acid rain-polluted environments.

\section{Materials and Methods}

The experiment was conducted in Zhejiang Agriculture and Forestry University of Lin'an, Hangzhou City, Zhejiang Province, China (119 $44^{\prime}$ E, $\left.30^{\circ} 16^{\prime} \mathrm{N}\right)$. The area experiences humid subtropical monsoon climate characterized with the following parameters: mean annual temperature of $16.4^{\circ} \mathrm{C}$ with maximum and minimum temperatures of 40.4 and $-9.2^{\circ} \mathrm{C}$ in July and January, respectively; annual total solar radiation of $1,847.3 \mathrm{~h}$; average annual precipitation of 1,628.6 mm; and mean relative humidity of $80 \%$.

Five wood species (C. sclerophylla, C. camphora, $M$. fordiana, P. massoniana, and E. glabripetalus) were used in the experiments. Two-year-old tree seedlings of each species were carefully selected and collected from broadleaf and coniferous forests. These seedlings were then cultured in pots (one plant per pot) filled with soil collected from the same forests. Afterward, the plants were placed in an open area. The experiment was conducted in a glasshouse, in which sides and rooftops were left open. In this setup, the trees did not receive any ambient rain.

Simulated acid rain (SAR) was prepared by adding $\mathrm{H}_{2} \mathrm{SO}_{4}$ and $\mathrm{HNO}_{3}$ to a base solution at a molar ratio of 1:1 $\left(\mathrm{H}_{2} \mathrm{SO}_{4}: \mathrm{HNO}_{3}\right)$. Deionized water was used as a diluent and the control sample. Solutions were further diluted with deionized water to obtain the required acidity levels. SAR exposure tests were conducted early in the morning or evening to avoid treatments under high temperatures and high irradiances during the day. Young trees were sprayed with a diluted SAR solution with various $\mathrm{pH}$ levels of 5.6 (control), 4.0 and 2.5 twice a day for a $1 \mathrm{hr}$ period at a rate of $2.2 \mathrm{~mm} \cdot \mathrm{hr}^{-1}$. Approximately $20 \mathrm{~mm}$ of precipitation was applied in the experiment for $5 \mathrm{~d}$. The frequency of SAR events and the quantity of SAR applied approximated longterm average for the study area. Deionized water was irrigated to avoid water deficit. Normal water and pest management were implemented during the culturing period.

Plant growth of five wood species was determined in September 2013 (from May to November). The plant height was measured with a ruler. Stem diameter was determined with a Vernier caliper. The chlorophyll content of the leaves was assessed using a SPAD-502 chlorophyll meter (Minolta, Osaka, Japan). Photosynthetic rates (oxygen production) were obtained from the foliage in the field on sunny days of the current year by using a LI-6400 photosynthesis meter (Li-Cor, USA) and a one-fourth liter chamber. All of the measurements were performed for $20 \mathrm{~s}$. The temperature control of LI-6400 was set to track ambient air temperature. The fluorescence characteristics of chlorophyll were also determined on sunny days using a portable, pulse amplitude-modulated fluorometer (PAM-2100, Walz, Effeltrich, Germany). The minimal (dark) fluorescence yield was obtained with weak modulated light (0.04 $\left.\mu \mathrm{mol} \cdot \mathrm{m}^{-2} \mathrm{~s}^{-1}\right)$. The maximal fluorescence yield was then obtained with a $2 \mathrm{~s}$ pulse of saturated light $\left(6,000 \mu \mathrm{mol} \cdot \mathrm{m}^{-2}\right.$ $\left.\mathrm{s}^{-1}\right)$. Actinic light intensity was $280 \mu \mathrm{mol} \cdot \mathrm{m}^{-2} \mathrm{~s}^{-1}$. All of the measurements were performed five times on the lamina, which is midway between the base and the tip of mature 
leaves. Photosynthesis measurements were analyzed using the repeat option in the analysis of variance procedure. Statistical significance was accepted at $\mathrm{P}<0.05$. Results were expressed as mean \pm standard deviation (SD).

\section{Results and Discussion}

Acid rain may affect photosynthesis by altering the chemical and morphological characteristics of leaves, $\mathrm{pH}$ balance in cells, carbon partitioning, membrane integrity of the chloroplast, and stomatal conductance [23]. Three influential types of acid rain on the tree species were observed after the trees were exposed to SAR: (a) inhibitory, (b) promotional, and (c) promotional at low acidity but inhibitory at high acidity (hormesis).

\section{(a) Inhibitory Type}

At different SAR treatments $P$. massoniana seedlings showed a significant decrease in growth (Figs. 1 and 2). Growth parameters such as plant height and stem diameter of $P$. massoniana decreased as the acidity of SAR increased. A decrease in chlorophyll content was also observed in P. massoniana leaves (Fig. 3). These changes in plant growth and of chlorophyll content of $P$. massoniana seedlings caused by SAR could be a consequence of reduced photosynthesis. The change in Pn of $P$. massoniana leaves exposed to SAR is shown in Fig. 4. The Pn of $P$. massoniana treated with SAR decreased by $20 \%$ and $34 \%$ at $\mathrm{pH} 4$ and 2.5 of SAR, respectively. This result suggested that $P$. massoniana was susceptible to acid rain. Thus the growth and Pn of tree species like $P$. massoniana was significant reduced in response to all SAR treatments belonged to the inhibitory type. With the increase of SAR acidity, the damage of seedlings became heavy when the acidity of SAR increased.

\section{(b) Promotional Type}

In contrast to $P$. massoniana, E. glabripetalus exhibited a strong tolerance to acid rain. Plant height, stem diameter, and chlorophyll content of E. glabripetalus were significantly higher than those of the control after these plants were exposed to SAR (Figs. 1-4). The Pn of $E$. glabripetalus was induced as the acidity of SAR increased. This result suggests that the nutrient element of SAR supported the growth of this species and impeded the possible

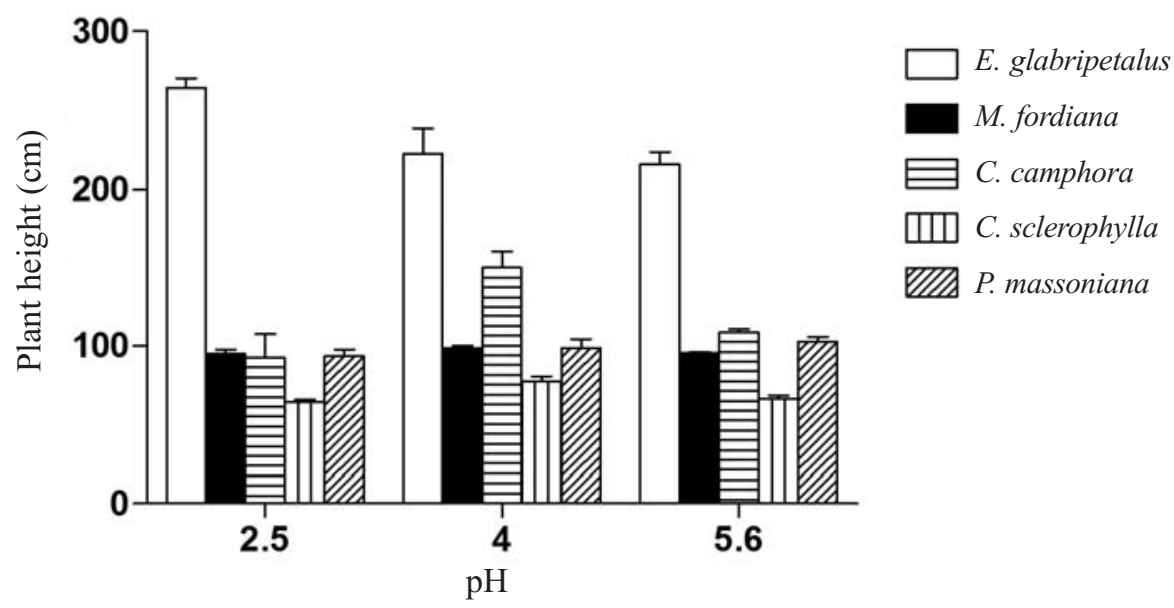

Fig. 1. Effects of acid rain on heights of five tree species. Values are mean $\pm \mathrm{SD}, \mathrm{n}=5$.

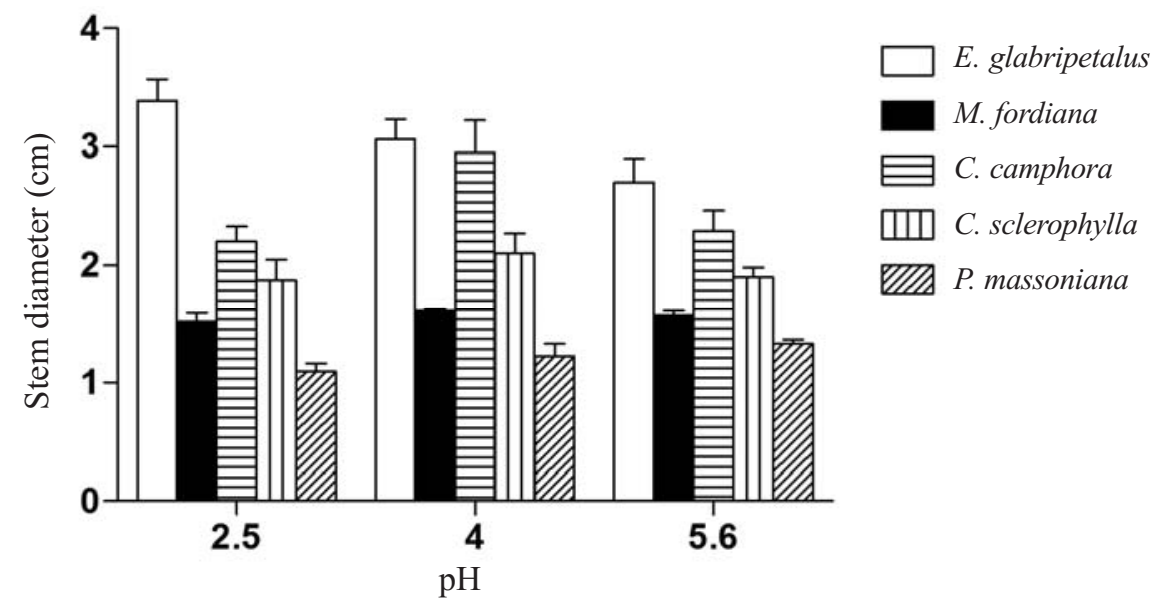

Fig. 2. Effects of acid rain on stem diameter of five tree species. Values are mean $\pm \mathrm{SD}, \mathrm{n}=5$. 
toxic effects of SAR on E. glabripetalus at different $\mathrm{pH}$ levels used in this study. Therefore, SAR promoted rather than inhibited E. glabripetalus seedlings. These tree species were reported to be highly endurable to acid rain after being processed by the SAR, the Pn of these species became significantly higher than control, suggesting that the promotional effect of the nutrient element of the SAR predominated over its toxic effect over the range of the investigated $\mathrm{pH}$. These plant species belonged to the promotional type to SAR.

\section{(c) Promotional Effect at Low Acidity but Inhibitory at High Acidity Type}

For M. fordiana, C. sclerophylla, and C. camphora, SAR elicited inhibitory effects on plant growth parameters at $\mathrm{pH}$ 2.5. At $\mathrm{pH} 4.0$, such inhibitory effects were no longer observed; instead, plant growth was promoted. Plant growth, chlorophyll content and the Pn of M. fordiana, $C$. sclerophylla, and C. camphora seedlings at $\mathrm{pH} 2.5$ were significantly lower than the control (Figs. 1-4). However, increased growth, chlorophyll content and Pn in these wood species were observed when exposed to $\mathrm{pH} 4.0$ compared with $\mathrm{pH}$ 5.6. Hence small amounts of SAR increased Pn.
These contrasting results indicated that acid rain may elicit two-sided effects - growth-promoting and -inhibiting effects. In particular, low acidity may promote growth and photosynthesis, whereas high acidity may inhibit the photosynthesis of the three plant species.

Acid rain has been considered a major stress factor affecting forest species; the negative effects of acid rain have been extensively studied because acid rain adversely affects forest health. Furthermore, this condition may cause foliar injury to plants and affect growth and yield. Although the direct impact of acidic precipitation on a forest is not yet completely understood, the susceptibility of trees to acid rain remarkably varies with tree species [24].

This study investigated the tolerance of five plant species to acid rain. Acid rain can cause a decrease in photosynthetic rate, loss from leaves, alterations of water balance, changes in enzyme activities, and ultrastructures of chloroplasts and mitochondria [25]. The results of our work showed that tree species differed in terms of their tolerance to acid rain, thus numerous indexes are necessary to evaluate stress resistance comprehensively [26, 27]. In the present study, the symptoms of five wood species on growth, height, chlorophyll content of leaves, and Pn of the five species were determined. These parameters were remarkably

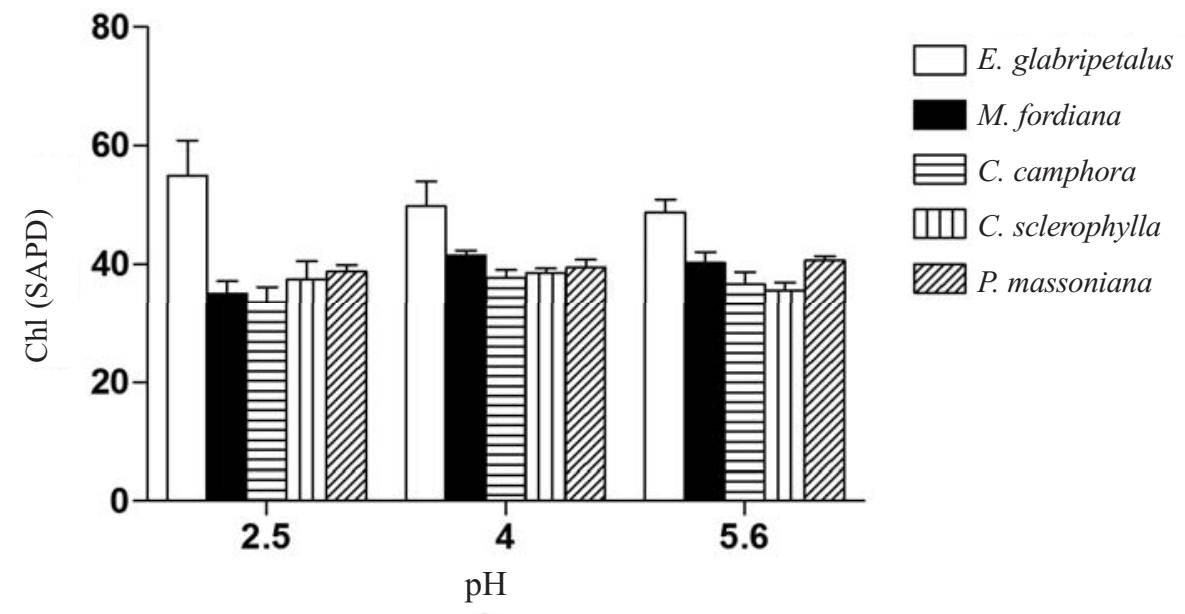

Fig. 3. Effects of acid rain on chlorophyll content of five tree species. Values are mean $\pm \mathrm{SD}, \mathrm{n}=5$.

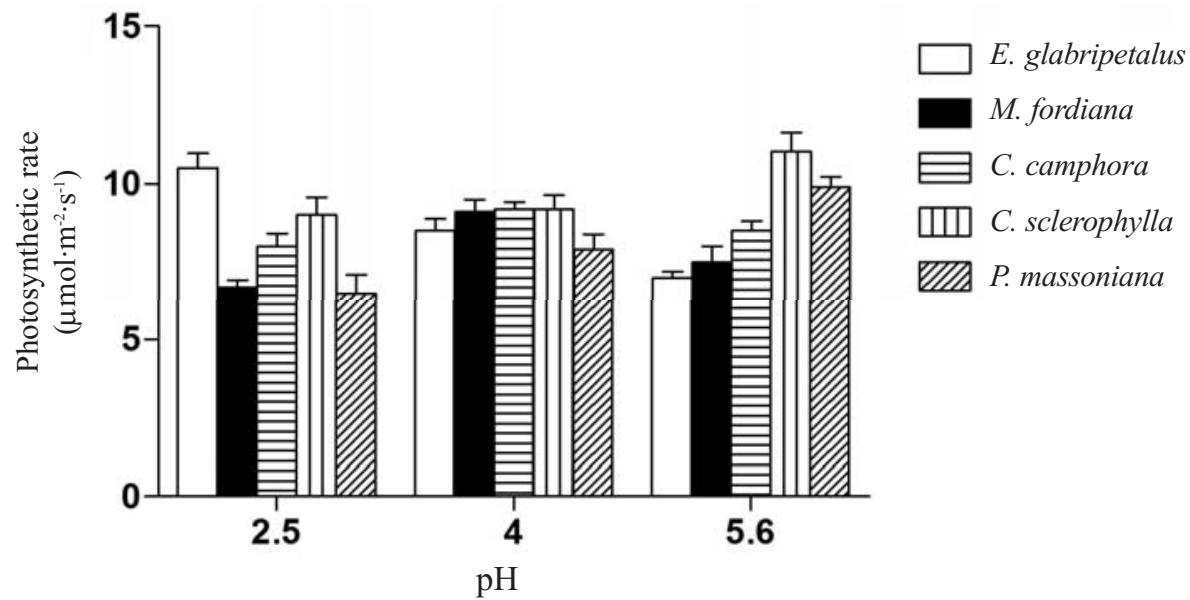

Fig. 4. Effects of acid rain on net photosynthetic rate of five tree species. Values are mean $\pm S D, n=5$. 
observed in the seedlings exposed to SAR at different $\mathrm{pH}$ levels compared with those in the control plants. P. massoniana seedlings showed significant reductions in growth and net photosynthetic rate in response to all SAR treatments. Liu also showed that photosynthetic rate of P. massoniana treated by SAR also decreased [28]. This was consistent with the finding of this study, both suggesting that $P$. massoniana is a sensitive species recommended for protection. These results also supported the idea that conifers were more susceptible to acid rain than broadleaf trees. The susceptibility of $P$. massoniana to acid rain may be one of the reasons for the dieback of $P$. massoniana in China. However, for M. fordiana, C. sclerophylla, and C. campho$\mathrm{ra}$, inhibitory effect was observed at $\mathrm{pH} 2.5$, while at $\mathrm{pH} 4.0$ the promotional effect became predominant. Thus, these three species could be used for re-vegetation of acid rainpolluted areas. E. glabripetalus exhibited the strongest resistance to acid rain. Plant height, stem diameter, and chlorophyll content of E. glabripetalus under SAR treatment were significantly higher than control. This result suggested that growth was promoted because nutrient elements in SAR elicited positive effects at different $\mathrm{pH}$ levels used in this study. Lee et al. reported that Quercus serrata and Alnus firma are species that can tolerate $\mathrm{SO}_{2}$ and $\mathrm{Al}$, respectively [29].

In addition, acid rain also elicited different sensitivity on the growth and photosynthesis of five tree species seedlings. The changes in growth and photosynthesis of the trees exposed to SAR treatments may be secondary negative effects of acidity. Seedling growth, chlorophyll content, and Pn of three species (C. sclerophylla, C. camphora, and M. fordiana) exposed to SAR were all in the order of moderate acid rain $>$ control $>$ heavy acid rain. This result suggested that moderate acid rain promoted growth and photosynthesis to some extent. The effects of SAR on different tree species in southern China corresponded to different susceptibilities to acid rain [30]. Therefore, acid rain poses a greater threat to P. massoniana growth in the long term. In this study, seedlings were used and may perfectly represent the mature tree. Further studies should be conducted to elucidate the responses of mature tree to acid rain [31]. In particular, among the five tree species, E. glabripetalus exhibited the highest tolerance to acid rain. SAR significantly promoted the growth of E. glabripetalus. The stress tolerance of these trees to SAR was observed in the following order: E. glabripetalus $>$ C. sclerophylla, C. camphora, M. fordiana $>$ P. massoniana. Although the sensitivities of tree species were totally different from one another, it is clear from these data that low $\mathrm{pH}$ falling in forest may result in a decrease or increase in growth potential over wide areas [32]. As acid deposition increases in the reserve, this may be one of the stresses currently leading to the decline of $P$. massoniana. However, SAR did not affect the final mortality of trees.

It is surprising, in our studies, that we also found exposure to SAR at $\mathrm{pH} 2.5$ to 5.6 did not elicit any significant effect on the final mortality of five tree species. In general, acid rain is harmful to vegetation by directly accumulating on the foliage or indirectly by leaching of nutrients from the soil [33]. Although forests are exposed to various threats, acid rain unlikely affects the final forestry damage. The overall results of the forestry damage may also be influenced by other environmental factors such as air temperature, light intensity, and soil water potential pollution [34]. Environmental stresses are supposed to affect photosynthetic processes in the long term. Therefore, further research is needed to assess the long-term effects of acidic precipitation and other environmental factors on different tree species to maintain ecological balance. Moreover, the effects of other environmental factors should be reduced to improve the accuracy and repeatability of this experiment.

Hence, this study was first to demonstrate that SAR, resembling the effects of acid rain under natural conditions, could elicit various effects on different plant species. The results showed that acid rain-tolerant plants could be used for ecological restoration in regions exposed to high incidences of acid rain. Furthermore, these results provide insight into how to protect the forest ecosystem environment and forest health from acid rain damage in the future. It also has important significance in sustaining ecological balance and to avoid acid rain-related irreversible harm to the world's environment.

\section{Acknowledgements}

Financial assistance for the study was provided by the Zhejiang Top Priority Forestry First-level Discipline Key Laboratory of Open Fund Project (No. KF201325) and National Natural Scientific Foundation of China (No. 30901153). The funders had no role in study design, data collection and analysis, decision to publish, or preparation of the manuscript.

\section{References}

1. ZHANG J.E., OUYANG Y., LING D.J. Impacts of simulated acid rain on cation leaching from the Latosol in south China. Chemosphere. 67, 2131, 2007.

2. LIU E.U., LIU C.P. Effects of simulated acid rain on the antioxidative system in Cinnamomum philippinense seedlings. Water Air Soil Poll. 215, 127, 2011.

3. JÓŹWIAK M.A., KOZŁOWSKI R., JÓŹWIAK M. Effects of Acid Rain Stemflow of Beech Tree (Fagus sylvatica L.) on Macro-Pedofauna Species Composition at the Trunk Base. Pol. J. Envrion. Stud. 22, 149, 2013.

4. LING D.J., HUANG Q.C., OUYANG Y. Impacts of simulated acid rain on soil enzyme activities in a latosol. Ecotox. Environ. Safe. 73, 1914, 2010.

5. AKSOY O., ERBULUCU T., ONER S., TEKELI I.B. Phytotoxic and genotoxic effects of water samples taken from the eastern channel of Kocaeli on Vicia faba and Zea mays. Fresen. Environ. Bull. 21, 1819, 2012.

6. CHEN J., LI W., GAO F. Biogeochemical effects of forest vegetation on acid precipitation-related water chemistry: a case study in southwest China. J Environ Monitor. 12, 1799, 2010.

7. TANG X.Y., LUO L., ZHANG H.J. The study on the spacetime distribution characteristics of acid rain in Southwest. Plateau and Mt Meteorolo Res. 29, 33, 2009. 
8. FLOREZ M., MARTÍNEZ E., CARBONELL M.V. Effects of Magnetic Field Treatment on Germination of Medicinal Plants Salvia officinalis L. and Calendula officinalis L. Pol. J. Envrion. Stud. 21, (1), 57, 2012.

9. CHEN J., WANG W.H., LIU T.W., WU F.H., ZHENG H.L. Photosynthetic and antioxidant responses of Liquidambar formosana and Schima superba seedlings to sulfuric-rich and nitric-rich simulated acid rain. Plant Physiol. Bioch. 64, 41, 2013.

10. MOHAMAD Z.A.G., MOH E.S., LEONG C.P. Effects of simulated acid rain on germination and growth of rice plant. J Trop Agric and Fd Sci. 36, 281, 2008.

11. BLANK L.W., ROBERTS T.M., SKEFFINGTON R.A. New perspectives on forest decline. Nature. 336, 27, 1988.

12. ANITA S., MADHOOLIKA A. Acid rain and its ecological consequences. J. Environ. Biol. 29, 15, 2008.

13. DUAN X.H., HU X.F., CHEN F.S., DENG Z.Y. Effects of Simulated Acid Rain and Aluminum Enrichment on Growth and Photosynthesis of Tea Seedlings. Adv Mater Res. 610, 181, 2013.

14. ARNOLD W.R., DIAMOND R.L., SMITH D.S. The Effects of Salinity, $\mathrm{pH}$, and Dissolved Organic Matter on Acute Copper Toxicity to the Rotifer, Brachionus plicatilis ("L" Strain). Arch. Environ. Con. Tox. 59, 225, 2010.

15. DENG S., GOU S., SUN B. Modeled Dosage - Response Relationship on the Net Photosynthetic Rate for the Sensitivity to Acid Rain of 21 Plant Species. B. Environ. Contam. Tox. 89, 251, 2012.

16. RUUHOLA T., RANTALA L.M., NEUVONEN S. Effects of long-term simulated acid rain on a plant-herbivore interaction. Basic Appl Ecol. 10, 589, 2009.

17. LIU J.X., ZHOU G.Y., YANG C.W., OU Z.Y., PENG C.L. Responses of chlorophyll fluorescence and xanthophyll cycle in leaves of Schima superba Gardn. \& Champ. and Pinus massoniana Lamb. to simulated acid rain at Dinghushan Biosphere Reserve, China. Acta Physiol. Plant. 29, 33, 2007.

18. XU W.T., PENG X.L., LUO Y.B. Physiological and biochemical responses of grapefruit seed extract dip on'Redglobe'grape. LWT-Food Sci Technol. 42, 471, 2009.

19. LARSSEN T., LYDERSEN E., TANG D., HE Y., GAO J., LIU H., DUAN L., SEIP H.M., VOGT R.D., MULDER J., SHAO M., WANG Y., SHANG H., ZHANG X., SOLBERG S., AAS W., OKLAND T., EILERTSEN O., ANGELL V., LIU Q., ZHAO D., XIANG R., XIAO J., LUO J. Acid rain in China. Environ. Sci. Technol. 40, 418, 2006.

20. WOOTTON-BEARD P.C., MORAN A., RYAN L. Stability of the total antioxidant capacity and total polyphenol content of 23 commercially available vegetable juices before and after in vitro digestion measured by FRAP, DPPH, ABTS and Folin-Ciocalteu methods. Food Res. Int. 44, 217, 2011.
21. XIE Z., DU Y., ZENG Y., LI Y., YAN M. Effects of precipitation variation on severe acid rain in southern China. $\mathrm{J}$ Geogr Sci. 19, 489, 2009.

22. SHUN Z., XIANGQUN Z., CHUN C. Leaching Behavior of Heavy Metals and Transformation of Their Speciation in Polluted Soil Receiving Simulated Acid Rain. Plos One. 7, $1,2012$.

23. SHUMEJKO P., OSSIPOV V., NEUVONEN S. The effects of simulated acid rain on the biochemical composition of Scots pine (Pinus sylvestris L.) needles. Environ Pollut. 92, 315, 1996.

24. GUO Z.H., LIAO B.H., HUANG C.Y. Mobility and speciation of $\mathrm{Cd}, \mathrm{Cu}$, and $\mathrm{Zn}$ in two acidic soils affected by simulated acid rain. J. Environ. Sci. 17, 332, 2005.

25. NURZYŃSKA-WIERDAK R. Ocimum basilicum L. - a valuable spice, medicinal and oleiferous plant. A review. Ann. UMCS. Lublin. 21, 20, 2012.

26. GABARA B., SKŁODOWSKA M., WYRWICKA A., GLIŃSKA S., GAPIŃSKAB M. Changes in the ultrastructure of chloroplasts and mitochondria and antioxidant enzyme activity in Lycopersicon esculentum Mill. leaves sprayed with acidrain. Plant Sci. 164, 507, 2003.

27. VAN H.M., PIQUERAS A., DEBERGH P.C. The evolution of photosynthetic capacity and the antioxidant enzymatic system during acclimatization of micropropagated Calathea plants. Plant Sci. 155, 59, 2000.

28. CAPPELLATO R., PETERS N.E., RAGSDALE H.L. Acidic atmo-spheric deposition and canopy interactions of adjacent deciduous and coniferous forests in the Georgia piedmont. Can. J. Forest Res. 23, 1114, 1993.

29. LEE C.S., LEE K.S., HWANGBO J.K., YOU Y.H., KIM J.H. Selection of tolerant plants and their arrangement to restore a forest ecosystem damaged by air pollution. Water Air Soil Poll. 156, 251, 2004.

30. WU F.Z., YANG W.Q., ZHANG J., ZHOU L.Q. Cadmium accumulation and growth responses of a poplar (Populus deltoids $\times$ Populus nigra) in cadmium contaminated purple soil and alluvial soil. J. Hazard. Mater. 177, 268, 2010.

31. ČUČULOVIĆ A., VESELINOVIĆ D., MILJANIĆ Š.S. 137Cs Desorp-tion from lichen Using Acid Solutions. Russian J Phys Chem. 83, 1547, 2009.

32. SMITH K L., STEVEN M.D., COLLS J.J. Use of hyperspectral derivative ratios in the red-edge region to identify plant stress responses to gas leaks. Remote Sens. Environ. 92, 207, 2004.

33. SIEPAK J., WALNA B., DRZYMAŁA S. Speciation of Aluminium Released Under the Effect of Acid Rain. Pol. J. Environ. Stud. 8, 55, 1999.

34. SINGH A., AGRAWAL M. Acid rain and its ecological consequences. J. Environ. Biol. 29, 15, 2008. 